\title{
Pengembangan Model Bisnis Daur Ulang Sampah Plastik di CV Majestic Buana Group
}

\author{
Business Model Development of Plastic Recycling Business in CV Majestic Buana Group
}

\author{
Heri Susanto $^{1 *}$, Arief Daryanto ${ }^{2}$, dan Iwan Setiawan ${ }^{3}$ \\ ${ }^{1}$ Magister Manajemen dan Bisnis, Sekolah Pascasarjana Institut Pertanian Bogor \\ Jl. Raya Pajajaran, Bogor 16151; E-mail: heri.susanto14@gmail.com; Hp: 081282684452 \\ ${ }^{2}$ Sekolah Pascasarjana Manajemen dan Bisnis, Institut Pertanian Bogor \\ Jl. Raya Pajajaran, Bogor 16151 \\ ${ }^{3}$ Center for Regional Resource Development and Community Development \\ Jl. Pandawa Raya 6 Bumi Indraprasta, Bogor 16153
}

\begin{abstract}
ABSTRAK
Sampah plastik yang tidak tertangani secara maksimal dapat mengganggu keseimbangan lingkungan. Sampah plastik harus dilihat sebagai sumber daya yang bernilai ekonomi dan bisa menjadi lahan bisnis. Tujuan penelitian membuat desain pengembangan model bisnis daur ulang sampah plastik di CV Majestic Buana Group (MBG). Penelitian menggunakan metode deskriptif dengan alat analisis Business Model Canvas, Metode Delphi, SWOT (Stregth, Weakness, Opportunities, Weakness) dan Blue Ocean Strategy. Penelitian dilakukan pada lima divisi perusahaan (produksi, keuangan, pemasaran, SDM dan pakar) dengan metode pemilihan responden secara purposive. Hasil penelitian menunjukkan pengembangan model bisnis diprioritaskan pada 3 unsur, yakni key resources, key partner, dan value propositions. Pengembangan unsur key resources dilakukan dengan membuat buku dan menjadi pembicara dalam seminar/training bisnis untuk menyesuaikan dengan arah pengembangan perusahaan yakni berbagi ilmu sebanyak mungkin pada masyarakat. Pengembangan unsur key resources didasarkan pada hasil evaluasi SWOT yang menunjukkan kelemahan yang paling tinggi dibandingkan unsur lainnya, sehingga perlu segera diantisipasi dengan cara menjalin kemitraan baru dengan sentra penghasil sampah plastik dan mulai mengurangi kerjasama komersial dengan pemasok bahan baku saat ini. Pengembangan unsur value propositions juga didasarkan pada hasil evaluasi SWOT yang menunjukkan adanya kekuatan utama dan peluang besar, sehingga harus dimanfaatkan untuk memerkuat model bisnis perusahaan, yakni menggunakan keahlian perusahaan untuk membuat desain mesin berskala rumah tangga.
\end{abstract}

Kata kunci: blue ocean strategy, daur ulang, model bisnis, sampah plastik

\section{ABSTRACT}

Plastic waste which is not handling properly will disrupt the enviromental balance. The plastic waste should be seen as a resource which has economic value and can be a chance of business. This study aim is to create business model development of plastic waste recycling in CV. Majestic Buana Group (MBG). The study uses descriptive analysis with the approachment method namely Business Model Canvas, Delphi Method, SWOT (Strength, Weakness, Opportunities, Threat) and Blue Ocean Strategy. It is done by purposive sampling method in the five company division (production, finance, marketing, HRD and expert). The result shows that the business model development can be amphasized on three elements; key resources, key partner and value propositions. The development of key resources can be done through writing business books and becoming a speaker of business seminar. It is adapted by the company vision to be able to transfer knowlegde as much as possible to the society. The key partners development is based on the result of SWOT analysis that shows major weakness compared to the other elements, therefore it is needed to give an anticipation by making new partnership with central

\footnotetext{
*) Korespondensi:

Jl. Raya Pajajaran, Bogor 16151; E-mail: heri.susanto14@gmail.com; Hp: 081282684452
} 
production of plastic waste dan reducing the commercial partnership with the existing plastic waste supplier. The development of value proposition element is also based on the result of SWOT analysis which shows major strength and has a great opportunity. It can be utilized to strengthen the business model by using the company's expertise to design a household scale machine.

Key words: blue ocean strategy, business model, recycling, plastic waste

\section{PENDAHULUAN}

Sampah merupakan barang atau benda berupa material sisa yang sudah tidak digunakan dan dibuang ke alam. Salah satu jenis sampah yang belum tertangani dengan baik dan berpotensi menimbulkan masalah lingkungan adalah sampah plastik. Kementrian Perindustrian dalam Harian Ekonomi Neraca (2013), menyatakan sebanyak $60 \%$ permintaan dan konsumsi produk plastik di Indonesia didorong oleh permintaan industri makanan dan minuman serta FMCG (Fast Moving Consumer Good). Menurut asumsi Kementerian Lingkungan Hidup (KLH, 2015), penduduk Indonesia menghasilkan 28,4 ribu ton sampah plastik/hari. Indonesia Solid Waste Association (InSWA) menyatakan jumlah sampah plastik di Indonesia telah mencapai 5,4 juta ton per tahun atau setara $14 \%$ dari total timbunan sampah (Antara, 2015).

Meidiana dan Gamse (2010) mengungkapkan hukum pengelolaan sampah yang belum diterapkan secara maksimal menyebabkan pengelolaan sampah di Indonesia tidak efisien. Di sisi lain, pertumbuhan penduduk yang terus meningkat, perubahan gaya hidup dan pola konsumsi masyarakat menjadi pendorong pertumbuhan sampah plastik. Sahwan (2005) mengungkapkan jumlah sampah plastik yang dibuang masyarakat Indonesia berkisar antara 10$15 \%$ dari total sampah yang dibuang. Nelms et al. (2015) menambahkan sampah plastik saat ini telah tersebar luas di lingkungan laut. Jambeck et al. (2015) mengungkapkan Indonesia menempati urutan ke-2 sebagai negara penimbun sampah plastik terbesar di dunia. Sebanyak $83 \%$ atau setara dengan 3,22 juta ton sampah plastik di perairan Indonesia tidak tertangani per tahunnya.

Tingginya volume sampah plastik yang tidak tertangani tersebut dapat memicu munculnya berbagai dampak negatif, baik terhadap lingkungan, hewan, maupun pada kesehatan manusia, sehingga penanganan sampah plastik perlu ditingkatkan. Suhartiningsih (2000) menyampaikan penanganan sampah harus dilihat sebagai sebuah sumber daya yang dapat diolah dan memiliki nilai ekonomi dan bisa menjadi lahan bisnis yang menguntungkan. Penanganan sampah plastik seharusnya tidak dilakukan dengan cara dibakar atau dibuang secara mudah, melainkan harus dapat memberi nilai tambah dan keuntungan bagi yang memanfaatkannya.

Salah satu pelaku usaha yang menangkap peluang tersebut adalah CV Majestic Buana Group (MBG). MBG merupakan perusahaan yang bergerak dibidang daur ulang sampah plastik yang berlokasi di Bekasi, Jawa Barat. MBG memiliki tiga produk utama, yakni cacahan plastik, mesin pencacah dan lakop sapu. Bahan baku utama pembuatan cacahan plastik adalah botol kemasan plastik. Bahan baku tersebut diolah dengan mesin pencacah plastik yang dibuat sendiri oleh MBG. Kondisi ini memungkinkan MBG memanfaatkan besarnya peluang ketersediaan bahan baku (sampah plastik) di Indonesia.

Upaya mengembangkan bisnis MBG tidak hanya dapat dilakukan melalui peningkatan kapasitas produksi, melainkan juga dapat dilakukan melalui inovasi model bisnis. Sejak didirikan tahun 2000 hingga saat ini, MBG telah memiliki 43 tenaga kerja. Perusahaan juga telah memeroleh banyak prestasi baik di tingkat nasional seperti Piagam Kalpataru 2010 maupun di tingkat ASEAN seperti Country Winner Malaysia-China Chamber of Commerce Green Award 2013.

Prestasi tersebut diraih MBG dengan kondisi manajemen/pengelolaan perusahaan yang dilakukan secara tradisional dan prinsip trial and error (coba-coba). Hal ini menjadikan MBG tidak memiliki blue print yang dapat digunakan untuk membantu memetakan potensi serta melihat peluang dan ancaman dalam bisnis daur ulang sampah plastik. Adanya inovasi model bisnis diharapkan dapat memberi solusi terhadap permasalahan sehingga MBG dapat memaksimalkan pemanfaatan sumber daya yang dimiliki dan lebih peka terhadap kondisi lingkungan bisnis. Dengan berkembangnya model bisnis MBG diharapkan dapat meningkatkan kapasitas dan perannya dalam menjaga kelestarian alam melalui pengelolaan sampah plastik berbasis ekonomi dan menjadi panutan dalam bisnis serupa. 
Tujuan penelitian menganalisis potensi pengembangan model bisnis daur ulang sampah plastik di CV MBG berdasarkan (1) arah pengembangan perusahaan, (2) hasil evaluasi model bisnis existing, serta (3) faktor lingkungan internal dan eksternal yang memengaruhi perusahaan.

\section{METODE PENELITIAN}

Penelitian dilakukan di CV MBG, Jl. Putat Cimuning 35, Kelurahan Cimuning, Kecamatan Mustika Jaya, Kota Bekasi, Jawa Barat. Pada bulan April-Agustus 2016. Penelitian dilakukan dengan metode deskriptif, menggunakan data primer dan sekunder. Pengumpulan data dan informasi dilakukan melalui observasi, wawancara, kuesioner dan studi literatur. Pengambilan responden dilakukan secara purposive sampling. Responden yang digunakan adalah tim manajemen MBG pada empat divisi perusahaan (pemasaran, keuangan, SDM dan produksi) dan pakar.

Tahap pengolahan dan analisis data yang dilakukan meliputi pemetaan model bisnis berdasarkan Business Model Canvas (BMC), analisis lingkungan internal dan eksternal dengan Metode Delphi, evaluasi sembilan unsur BMC menggunakan SWOT dan membuat desain pengembangan model bisnis berdasarkan perspektif Blue Ocean Strategy (BOS) (Kim dan Mauborgne, 2005).

\section{HASIL DAN PEMBAHASAN}

MBG merupakan perusahaan daur ulang sampah botol plastik yang berdiri sejak tahun 2000. Kegiatan bisnis MBG dibagi 4 sub grup, yakni (1) Majestic Buana Cipta Cemerlang yang fokus pada pengolahan botol plastik menjadi cacahan, (2) Majestic Buana Cipta Kreasi fokus pada bidang pembuatan mesin, (3) Majestic Buana Cipta Guna fokus pada bidang pembuatan lakop sapu, dan (4) Majestic Buana Mitra Selaras fokus pada penanganan pelanggan. Pengembangan bisnis perusahaan diarahkan pada upaya untuk berbagi ilmu dan pengalaman bisnis daur ulang sampah plastik kepada masyarakat agar kesuksesan berbisnis daur ulang sampah plastik dapat diraih oleh orang lain. Selain itu, dimasa mendatang perusahaan ingin memberikan $90 \%$ keuntungan perusahaan kapada karyawan.
Tren pendapatan MBG pada tahun 20062015 memperlihatkan adanya peningkatan, meskipun megalami fluktuasi. Pada tahun 2015 pendapatan memperlihatkan adanya penurunan 0,8\% dibandingkan tahun sebelumnya, karena perusahaan menahan penjualan produk cacahan plastik akibat dari gejolak ekonomi global yang menyebabkan ketidakstabilan harga jual.

\section{Pemetaan Model Bisnis}

Pemetaan model bisnis MBG dilakukan untuk memeroleh gambaran informasi yang mendalam terhadap bisnis yang dijalankan. Menurut Fielt (2011), bisnis model dapat meningkatkan pemahaman tentang konseptualisasinya. Hasil penelitian memperlihatkan tiga sub grup MBG memiliki komponen pendukung yang berbeda pada beberapa unsur model bisnis. Perbedaan kompenen tersebut terdapat pada unsur key partners, value propositions dan customer segments. Hasil pemetaan komponen dari setiap unsur model bisnis MBG berdasarkan BMC terlihat pada Gambar 1.

\section{a. Customer Segments (CS)}

Bisnis MBG bersifat Business to Business (B2B). Pelanggan membeli produk perusahaan untuk diperjualbelikan lagi atau diolah menjadi produk akhir (end product). Masing-masing produk memiliki customer segments (kelompok pelanggan) yang berbeda. Kelompok pelanggan produk cacahan plastik meliputi traders, eksportir dan perusahaan pengguna (end user). Kelompok pelanggan mesin berasal dari berbagai kalangan, seperti perorangan, institusi pemerintah dan perusahaan swasta. Kelompok pelanggan lakop sapu adalah produsen sapu.

\section{b. Value Propositions (VP)}

Value propositions (nilai yang ditawarkan) pada setiap produk berbeda-beda. Value yang diberikan pada cacahan plastik adalah kebersihan dan kemurnian (purity) hasil cacahan. Value pada mesin pencacah berupa rendahnya biaya perawatan, kemudahaan mengoperasikan, desain ergonomis, efektifitas kinerja, garansi kerusakan selamanya, pemberian training dan instalasi mesin gratis, serta jaminan pasar. Value pada lakop sapu adalah bentuknya yang ergonomis dan kemurnian bahan baku. 


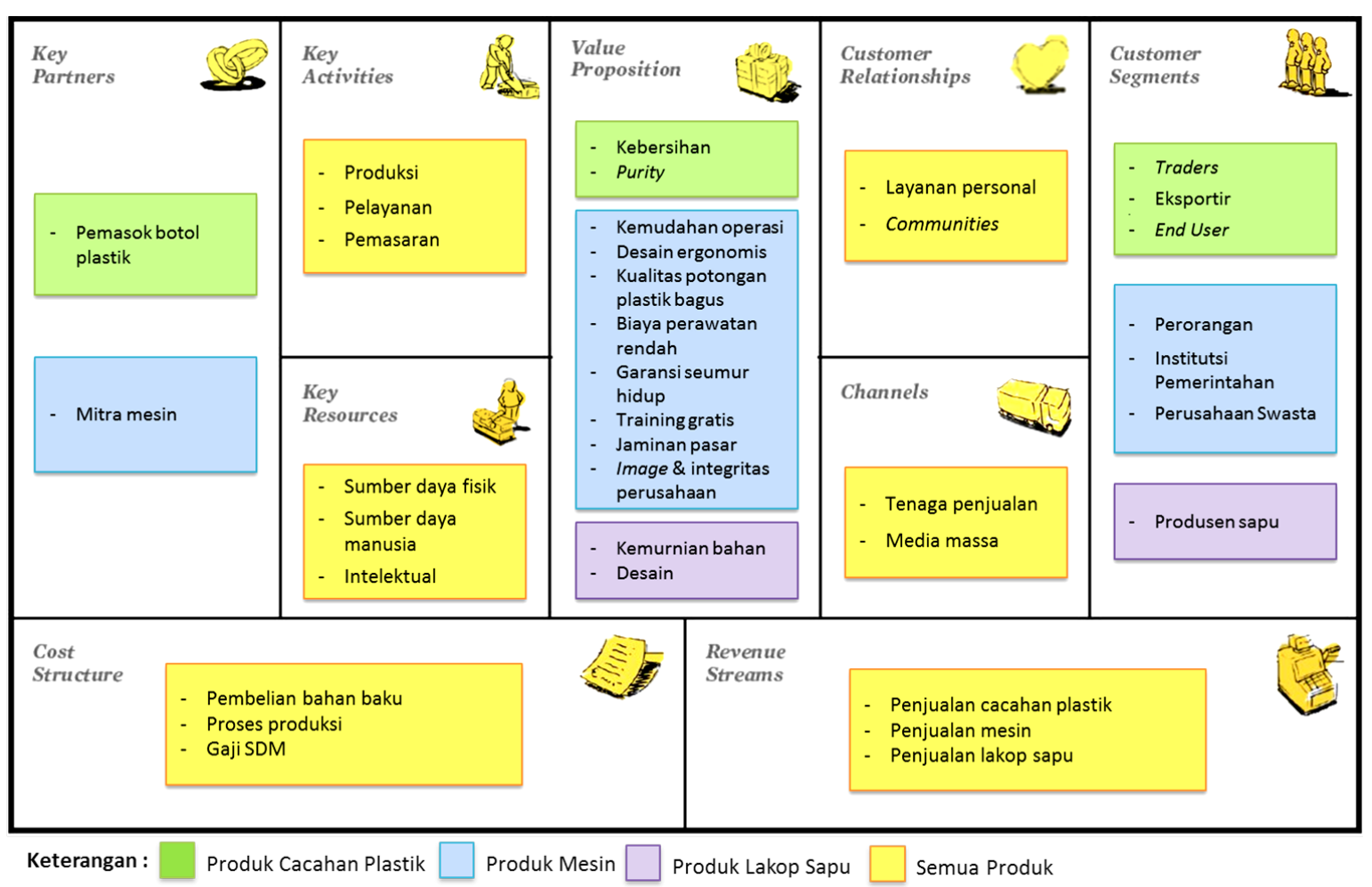

Gambar 1. Pemetaan model bisnis CV Majestic Buana Group

\section{c. Channels (Ch)}

Channels (saluran) yang digunakan adalah media massa dan saluran langsung, yakni perusahaan melakukan penjualan produk secara langsung kepada pelanggan. Dengan saluran ini MBG dapat berinteraksi dan menyampaikan value propotitions produk secara langsung kepada pelanggan, mengevaluasi dan mengetahui perkembangan penerimaan pelanggan terhadap value yang ditawarkan, serta dapat memperoleh margin penjualan yang lebih besar.

\section{d. Customer Relationships (CR)}

Customer relationships (hubungan bisnis) MBG bersifat personal assistance (bantuan personal) dengan para kelompok pelanggan cacahan plastik. Jenis hubungan dengan pelanggan mesin bersifat dedicated personal assistance (bantuan personal khusus), yakni perusahaan memberi pelayanan khusus dengan cara mengirimkan karyawan untuk melatih (memberi training) dan membantu melakukan proses instalasi mesin. Jenis hubungan lain yang dibangun adalah communities (komunitas), yakni perusahaan membantu dan memfasilitasi terjalinnya hubungan saling menguntungkan antara mitra perusahaan dengan sentra penghasil sampah plastik seperti bank sampah.

\section{e. Revenue Streams (RS)}

Revenue streams MBG dipengaruhi oleh penjualan aset kepada para pelanggan, yakni penjualan hak kepemilikan atas produk fisik berupa cacahan plastik, mesin pencacah dan lakop sapu. Penjualan aset/produk tersebut dipengaruhi oleh kesediaan membayar pelanggan terhadap value yang ada pada setiap prouduk.

\section{f. Key Activities (KA)}

Aktivitas kunci MBG dikelompokkan menjadi tiga, yakni produksi, pelayanan dan pemasaran. Aktivitas produksi cacahan plastik meliputi pembelian bahan baku, pencacahan, pencucian dan quality control. Aktivitas produksi mesin meliputi pembelian bahan baku, pemotongan dan perakitan. Pada lakop sapu meliputi pembelian bahan baku, kemurnian dan blowing. Aktivitas kunci pelayanan hanya dilakukan pada pelanggan mesin.

\section{g. Key Resources (KR)}

Key resources MBG meliputi sumber daya fisik, Sumber Daya Manusia (SDM) dan aset intelektual. Sumber daya fisik perusahaan berupa tanah dan bangunan pabrik, mesin, kendaraan, bahan baku dan jaringan pemasok. Bahan baku dan jaringan pemasok merupakan bagian terpenting pada produk cacahan plastik dan lakop sapu. 
SDM atau karyawan yang terlatih termasuk owner perusahaan merupakan aset penting MBG. Owner MBG juga memiliki kekayaan intelektual yang berupa kemampuan melakukan inovasi mesin pencacah plastik.

\section{h. Key Partnerships (KP)}

Key partnertships merupakan mitra kerja sama pengoperasian model bisnis MBG. Jenis kemitraan yang dibangun berupa hubungan bisnis antara pembeli dan pemasok. Mitra utama MBG dibedakan menjadi dua, yakni mitra pemasok bahan baku botol plastik dan mitra pemasok cacahan botol plastik. Mitra pemasok botol plastik antara lain pemulung, pengepul dan lapak (bandar). Mitra pemasok cacahan plastik berasal dari para pembeli mesin. Pembeli mesin secara otomatis menjadi mitra MBG untuk menjamin pasar dari cacahan plastik yang dihasilkan.

\section{i. Cost Structures (CS)}

Cost structure model bisnis MBG bersifat value driven atau terpacu nilai, yakni perusahaan berfokus untuk memaksimalkan penciptaan nilai dibandingkan dengan biaya produksi. Hal ini terlihat dari upaya perusahaan untuk menciptakan dan memberikan kualitas terbaik pada hasil cacahan plastik, mesin dan lakop sapu.

\section{Analisis Lingkungan Internal}

Analisis ini dilakukan dengan menggali informasi aspek internal model bisnis MBG melalui wawancara dan kuesioner. Hasil yang diperoleh digunakan sebagai bahan pertimbangan untuk merumuskan pengembangan model bisnis yang lebih kuat dan kompetitif dari sisi internal. Analisis ini dilakukan pada empat aspek lingkungan internal yakni product, customer interface, infrastructure management, dan financial aspect (Osterwalder dan Pigneur, 2015).

\section{a. Produk}

Berdasarkan hasil identifikasi, faktor-faktor yang memengaruhi produk MBG meliputi mutu, kuantitas, bahan baku, proses produksi dan SDM. Perusahaan memberikan penilaian yang sangat penting terhadap mutu, bahan baku, proses produksi dan kinerja SDM. Hal ini menunjukkan mutu produk harus diutamakan dalam daur ulang sampah plastik. Menurut perusahaan, mutu produk sangat memengaruhi harga jual dan keputusan membeli calon pelanggan.

\section{b. Customer Interface}

Terdapat tiga hal yang memengaruhi customer interface MBG yakni jarak, kedekatan personal dan informasi media. Jarak merupakan faktor pertama yang mendapatkan penilaian sangat peting dalam customer interface. Jauhnya jarak antara pelang-gan dengan perusahaan memengaruhi cara perusahaan untuk memberikan pelayanan, seperti pengiriman mesin dan pembelian bahan baku cacahan plastik. Semakin jauh jarak maka biaya (cost) pengiriman mesin atau cacahan plastik akan semakin tinggi dan dan waktu yang diperlukan semakin panjang (lama).

\section{c. Infrastructure Management}

Bagi MBG hal terpenting dalam infra-structure management adalah keberadaan SDM (karyawan). Hal-hal yang memengaruhi SDM dalam infrastructure management MBG adalah keterampilan, jumlah, motivasi dan sistem reward (imbalan). Keterampilan karyawan dinilai biasa dalam bisnis daur ulang sampah plastik tidak memerlukan skill khusus. Tingkat keterampilan yang dibutuhkan tergolong rendah dan mudah dipelajari melalui praktek langsung. Faktor lain seperti motivasi dan sistem reward dinilai penting untuk meningkatkan kinerja karyawan.

\section{d. Financial Aspect}

Aspek finansial yang dianalisis dalam pelaksanaan bisnis MBG meliputi kemampuan modal perusahaan, modal tambahan dalam bisnis, hubungan baik dengan penanam modal, pengelolaan keuangan perusahaan, struktur modal kerja, harga jual produk dan sistem akunting. Dari berbagai aspek tersebut penilaian terpenting terdapat pada harga jual produk, dikarenakan penjualan merupakan revenue streams terpenting. Pengaruh faktor finansial lainnya dinilai biasa, karena dalam bisnis ini tidak memerlukan nilai finansial yang terlalu tinggi.

\section{Analisis Lingkungan Eksternal}

Analisis lingkungan eksternal MBG dilakukan dengan Metode Delphi untuk memperoleh pemahaman yang baik pada lingkungan eksternal perusahaan yang memengaruhi model bisnis. Hasil analisis memerlihatkan pengaruh kekuatan pasar 28,48\%, kekuatan industri 25,82\%, tren kunci $24,93 \%$, dan kekuatan ekonomi makro $20,77 \%$ 


\section{a. Kekuatan Pasar}

Kekuatan pasar menjadi faktor lingkungan eksternal yang paling memengaruhi model bisnis daur ulang sampah plastik (28,48\%). Peubah yang mendapat penilaian sangat penting adalah isu-isu pasar, segmen pasar, kebutuhan dan permintaan, biaya perpindahan dan daya pikat pendapatan. Masing-masing peubah tersebut dinilai memiliki pengaruh yang sangat tinggi dalam bisnis daur ulang sampah plastik, sehingga perlu diperhatikan oleh pelaku bisnis daur ulang plastik. Peubah segmen pasar dipengaruhi oleh keberadaan industri berbahan baku plastik dan industri daur ulang yang dinilai berpengaruh nyata terhadap penyerapan produk cacahan plastik. Peubah kebutuhan permintaan sangat dipengaruhi oleh pola konsumsi dan gaya hidup masyarakat yang menginginkan bahan kemasan serba praktis. Hal ini senada dengan pernytaan Chaerul et al. (2014) yang menyatakan bahwa pertumbuhan ekonomi, perubahan pola produksi dan konsumsi mendorong pesatnya pertumbuhan sampah kemasan plastik. Peubah biaya perpindahan dipengaruhi secara nyata oleh harga jual produk cacahan plastik, harga jual mesin, jasa pelayanan after sales dan onderdil mesin/suku cadang. Komponen yang berpengaruh nyata pada peubah daya pikat pasar adalah harga jual dan kemudahan menjual produk cacahan plastik. Peubah isu pasar dipengaruhi oleh nilai ekonomi dan perkembangan industri.

\section{b. Kekuatan Industri}

Kekuatan industri memeroleh persentase penilaian tertinggi kedua dalam analisis faktor lingkungan industri daur ulang sampah plastik $(25,82 \%)$. Peubah yang sangat berpengaruh adalah keberadaan pemain baru, produk dan jasa pengganti, serta pemasok/pelaku rantai nilai. Jumlah pemain baru saat ini cenderung rendah. Beberapa hal yang perlu diperhatikan pemain baru dalam industri daur ulang sampah plastik adalah skala ekonomi, biaya peralihan, akses ke pemasok, keunggulan biaya dan hubungan dengan mitra. Produk pengganti daur ulang sampah plastik adalah minyak bumi. Rendahnya harga minyak bumi dapat mengurangi permintaan produk daur ulang plastik, karena pengguna lebih suka menggunakan minyak bumi sebagai bahan baku pembuatan produk berbahan dasar plastik dibandingkan dengan cacahan plastik. Pemasok dan pelaku rantai nilai yang berperan aktif menyediakan bahan baku (botol plastik) adalah pemulung, pengepul dan lapak (bandar). Faktor lain yang dianggap penting dalam persaingan industri adalah pesaing dan stakeholders. Keberadaan pemain besar dapat menjadi ancaman bagi pemain baru, karena telah memiliki jaringan pemasok yang luas dan dukungan modal cukup kuat. Keberadaan stakeholders seperti peneliti, pemerintah dan media masa dinilai penting untuk mendorong pertumbuhan dan antusiasme, serta peran masyarakat terhadap bisnis sampah plastik.

\section{c. Tren Kunci}

Analisis tren kunci mendapat persentase penilaian 24,93\%. Analisis ini dilakukan pada berbagai faktor lingkungan yang memengaruhi kecenderungan bisnis daur ulang sampah plastik dimasa mendatang. Peubah masyarakat dan budaya dinilai memiliki pengaruh tinggi terhadap konsumsi dan permintaan produk berbahan plastik. Hal ini dipengaruhi oleh peningkatan standar hidup masyarakat yang memengaruhi perubahan gaya hidup, perubahan pola konsumsi dan pendidikan. Peubah teknologi yang dipengaruhi oleh kemajuan teknologi informasi dan komunikasi, kebutuhan inovasi produk, riset dan pengembangan teknologi, teknologi industri pendukung dan harga teknologi produksi yang digunakan. Peubah yang memengaruhi regulasi dan politik adalah adanya otonomi daerah, kebijakan moneter, peraturan tentang keamanan dan kesehatan, peraturan kepemilikan usaha, peraturan lingkungan, peraturan perdagangan luar negeri, sistem perpajakan dan deregulasi. Komponen peubah sosio-ekonomi yang dinilai berpengaruh adalah kurs valuta asing, pertumbuhan ekonomi, konsumsi masyarakat dan pertumbuhan produk domestik bruto.

\section{d. Kekuatan Ekonomi Makro}

Pengaruh kekuatan ekonomi makro memperoleh persentase terendah $(20,77 \%)$ dari para pakar. Menurut pakar, bisnis daur ulang plastik di Indonesia saat ini lebih banyak dipengaruhi oleh faktor-faktor dalam negeri. Faktor ekonomi makro yang dinilai penting dan memiliki pengaruh signifikan terhadap bisnis daur ulang plastik adalah kondisi pasar global khususnya harga jual minyak bumi.

\section{Evaluasi Model Bisnis}

Evaluasi model bisnis dilakukan dengan analisis SWOT untuk memberikan 4 perspektif penilaian (strengths, weakness, opportunities, threats) pada 9 unsur model bisnis MBG. Analisis ini 
mengacu pada pemikiran bagaimana memaksimalkan kekuatan dan peluang, serta secara bersamaan dilakukan upaya untuk meminimalkan kelemahan dan ancaman (Rangkuti 2004). Hasil yang diperoleh digunakan sebagai dasar inovasi dan pembaruan model bisnis. Hasil evaluasi tersebut terlihat pada Gambar 2.

\section{a. Customer Segments}

Hasil evaluasi memerlihatkan bahwa customer segments MBG memiliki kekuatan sangat tinggi $(4,67)$, kelemahan sangat rendah $(1,33)$, peluang tinggi $(4,33)$ dan ancaman rendah (2). Tingginya nilai kekuatan diperoleh dari kemampuan MBG untuk terus meningkatkan jumlah dan menjaga loyalitas pelanggan. Tingginya nilai peluang diperoleh dari besarnya kesempatan untuk memberikan pelayanan yang lebih baik pada setiap segmen pelanggan untuk mendapatkan pasar yang terus tumbuh.

\section{b. Value Propositions}

Hasil evaluasi value propotitions MBG menunjukkan nilai kekuatan sangat kuat $(4,75)$, kelemahan sangat rendah $(1,00)$, peluang sangat tinggi $(5,00)$ dan ancaman sangat tinggi $(4,5)$. Tingginya kekuatan dipengaruhi oleh kemampuan MBG dalam menyelaraskan antara kualitas produk dengan kebutuhan pelanggan sehingga memberikan tingkat kepuasan tinggi serta memberi dampak jaringan kuat. Tingginya nilai peluang dipengaruhi oleh adanya peluang melakukan perluasan terhadap value produk, banyaknya pekerjaan lain yang dapat dilakukan termasuk mengintegrasikan produk dan jasa untuk menjaga loyalitas dan meningkatkan pendapatan berulang. Tingginya ancaman dipengaruhi oleh keberadaan produk subtitusi seperti minyak bumi dan pesaing yang mengancam menawarkan harga dan nilai yang lebih baik.

\section{c. Customer Relationships}

Hasil evaluasi customer segments perusahaan memerlihatkan adanya kekuatan sangat tinggi $(5,00)$, kelemahan sangat rendah $(1,00)$, peluang sangat besar $(4,67)$ dan ancaman tinggi $(4,00)$. Tingginya kekuatan dipengaruhi oleh kemampuan MBG dalam menjaga hubungan yang baik dengan pelanggan melalui mutu hubungan yang baik, biaya perpindahan yang tinggi dan kekuatan citra perusahaan. Tingginya nilai peluang dipengaruhi oleh adanya kesempatan mempererat hubungan dengan pelanggan, meningkatkan personalisasi dan biaya perpindahan pelanggan serta memilih pelanggan potensial. Ancaman mendapatkan penilaian yang tinggi karena besarnya kemungkinan hubungan yang terancam memburuk karena faktor lokasi.

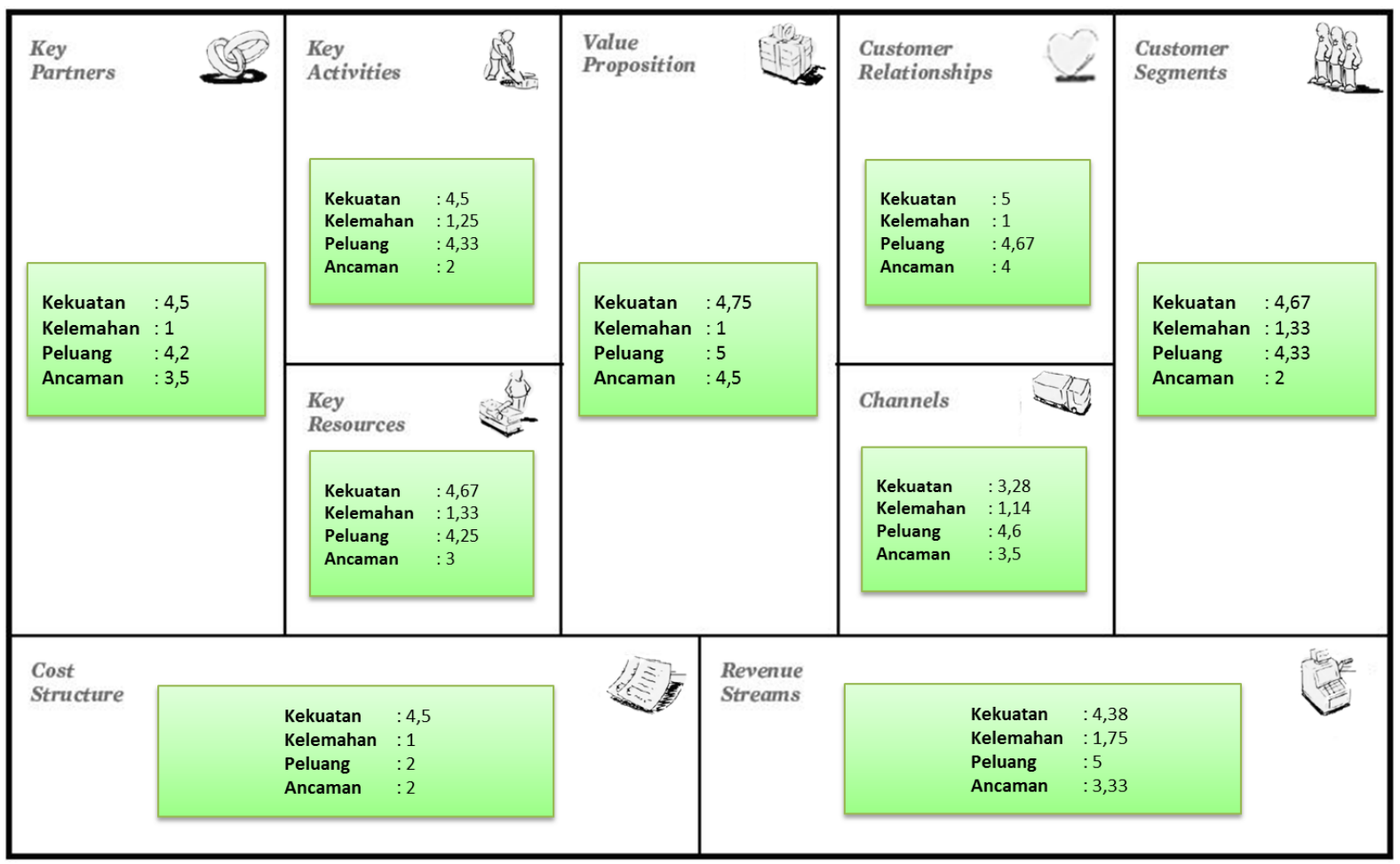

Keterangan Skor: 1 : Sangat Rendah; 2 : Rendah; 3 : Sedang; 4 : Tinggi; 5 : Sangat Tinggi

Gambar 2. Evaluasi elemen model bisnis CV Majestic Buana Group 


\section{d. Channels}

Channels yang dimiliki MBG adalah tenaga penjualan langsung dan media masa mendapat penilaian evaluasi kekuatan sedang $(3,28)$, kelemahan sangat rendah $(1,14)$, peluang sangat tinggi $(4,6)$ dan ancaman yang tinggi $(3,5)$. Kekuatan channels perusahaan dipengaruhi oleh kapasitas jangkauan, efektifitas dan efisiensi saluran yang dimiliki. Tingginya peluang terdapat pada adanya berbagai saluran untuk mendapatkan mitra baru, menyelaraskan saluran dengan pelanggan dan meningkatkan margin. Tingginya ancaman dipengaruhi keberadaan pesaing yang mengancam saluran, sehingga menjadi tidak relevan untuk digunakan dalam jangka panjang.

\section{e. Revenue Streams}

Hasil evaluasi revenue streams menunjukkan kekuatan tinggi $(4,38)$, kelemahan rendah $(1,75)$, peluang sangat tinggi $(5,00)$ dan ancaman sedang $(3,33)$. Tingginya nilai kekuatan diperoleh dari kemampuan perusahaan untuk memeroleh pendapatan berulang dan berkelanjutan karena MBG hanya mengenakan biaya pada apa yang benar-benar diinginkan oleh pelanggan dan menetapkan harga sesuai kemauan membayar pelanggan. Unsur ini menunjukkan adanya peluang untuk menggantikan transaksi satu kali menjadi transaksi berulang, melakukan penjualan silang, menaikkan harga pada nilai yang bersedia dibayar pelanggan. Ancaman yang terdapat pada unsur ini adalah ketergantungan pada satu arus pendapatan dan penurunan margin, karena persaingan dan teknologi.

\section{f. Key Activities}

Evaluasi key activities MBG memperlihatkan kekuatan sangat tinggi $(4,5)$, kelemahan sangat rendah $(1,25)$, peluang tinggi $(4,33)$ dan ancaman rendah $(2,00)$. Kekuatan KA yang dimiliki MBG adalah kemampuan untuk menjalankan aktivitas kunci secara efisien dan keseimbangan untuk melakukan in-house dan outsourching. Peluang yang terdapat pada unsur ini adalah membakukan aktivitas kunci melalui peningkatan efisiensi secara umum dengan pemanfaatan teknologi.

\section{g. Key Resources}

Hasil evaluasi unsur KR menunjukkan adanya kekuatan sangat tinggi $(4,67)$, kelemahan rendah $(1,33)$, peluang yang tinggi $(4,25)$ dan ancaman sedang $(3,00)$. Kekuatan yang dimiliki dalam unsur ini adalah kemampuan perusahaan untuk memprediksi sumber daya yang dibutuhkan dan memanfaatkan sumber daya tersebut dalam jumlah tepat. Peluang unsur ini terdapat pada keberadaan sumber daya utama yang mungkin diperoleh dan digali dari mitra, serta kepemilikan sumber daya intelektual, yakni kemampuan menginovasi mesin untuk terus ditingkatkan. Acaman yang bisa terjadi pada unsur ini adalah gangguan pasokan bahan baku karena persaingan harga beli dengan pesaing.

\section{h. Key Partner}

Keberadaan key partner mendapat hasil penilaian kekuatan sangat kuat $(4,50)$, kelemahan sangat rendah $(1,00)$, peluang tinggi $(4,20)$ dan ancaman tinggi $(3,50)$. Kekuatan MBG dalam unsur ini dipengaruhi oleh kemampuan perusahaan untuk menikmati hubungan yang baik dengan mitra dan fokus bekerja dengan mitra bila diperlukan. Peluang yang ada meliputi kesempatan berkolaborasi yang lebih kuat dengan mitra, melakukan penjualan silang dan memanfaatkan mitra untuk menjangkau pelanggan dengan lebih baik. Ancaman yang terdapat dalam unsur ini adalah kehilangan mitra dan kemungkinan mitra berkolaborasi dengan pesaing.

\section{i. Cost Structure}

Hasil evaluasi cost structure MBG menunjukan kekuatan sangat tinggi $(4,50)$, kelemahan sangat rendah $(1,00)$, peluang rendah $(2,00)$ dan ancaman yang rendah $(2,00)$. Kekuatan unsur ini dipengaruhi oleh kemampuan MBG untuk memprediksi biaya dan mampu mendapatkan keuntungan dari skala ekonomi yang didukung oleh struktur biaya yang sesuai dengan model bisnis dan efisiensi dari segi operasional. Unsur ini memiliki peluang yang rendah melakukan pengurangan biaya dan acaman yang rendah pada semua biaya dalam bisnis daur ulang sampah plastik yang dapat diprediksi dan tidak ada komponen biaya yang dapat tumbuh lebih cepat dari pendapatan perusahaan.

\section{Desain Pengembangan Model Bisnis}

Pengembangan model bisnis MBG dilakukan dengan perspektif BOS melalui kerangka kerja empat tindakan (mengeliminasi, mengurangi, menciptakan, meningkatkan). Kerangka kerja tersebut digunakan untuk mempertanyakan sembilan unsur model bisnis yang ada dengan cara mengkaji, menggali, dan menampilkan secara visual perubahan yang terjadi pada setiap unsur model bisnis, sehingga membantu memahami pengaruh perubahan satu unsur terhadap 
unsur lainnya. Menurut Amanullah et al. (2015) masing-masing unsur BMC dapat menjadi titik awal pengembangan dan menghasilkan desain model bisnis baru sebanyak mungkin. Dengan demikian, kombinasi BMC dan BOS dapat menghasilkan alternatif strategi pengembangan model bisnis yang lebih dari satu atau sesuai dengan unsur yang ingin dikembangkan. Ketentuan yang digunakan untuk memilih unsur yang dikembangkan, adalah (1) kesesuaian dengan arah pengembangan perusahaan, (2) hasil evaluasi sembilan unsur model bisnis dan (3) hasil evaluasi faktor lingkungan (internal dan eksternal). Berdasarkan ketentuan tersebut maka pengembangan secara bertahap dapat dilakukan pada tiga unsur yakni key resources, key partners dan value propositions.

\section{Pengembangan Model Bisnis I}

Pengembangan model bisnis I dilakukan melalui unsur key resources. Pengembangan ini disesuaikan dengan salah satu arah pengembangan MBG, yakni keinginan untuk membagikan ilmu dan pengalaman bisnis daur ulang sampah kepada masyarakat secara luas. Unsur yang paling sesuai dengan hal tersebut adalah key resources, khususnya SDM. Berdasarkan hasil evaluasi model bisnis, unsur key resources memiliki kekuatan dan peluang yang tinggi untuk dikembangkan. Kekuatan key resources terutama didukung oleh kemampuan perusahaan untuk mengelola SDM yang sangat baik dan kekayaan intelektual owner dalam melakukan inovasi mesin pencacah plastik. Kemampuan dan keahlian owner MBG dalam mengelola bisnis daur ulang sampah plastik telah dibuktikan dengan berbagai prestasi dan penghargaan yang telah diraih. Hal tersebut dapat ditingkatkan sebagai upaya menyelaraskan arah pengembangan perusahaan, yakni berbagi ilmu dan pengalaman (transfer knowledge) dalam bentuk penulisan buku dan seminar/training bisnis. Pengaruh peningkatan fungsi SDM (key resources) terhadap delapan unsur model bisnis lainnya seperti pada Gambar 3

\section{a. Key Activities}

Kegiatan transfer knowledge dapat menjadi sarana MBG untuk melakukan promosi dan pemasaran produk-produk perusahaan. Untuk mendukung tercapainya manfaat tersebut maka key activities yang dapat diciptakan adalah menulis buku bertema bisnis daur ulang sampah dan kegiatan mengisi kegiatan seminar/training bisnis. Keduanya dapat saling melengkapi dan menjadi bagian dalam kegiatan sub grup perusahaan yakni Majestic Buana Cipta Selaras.

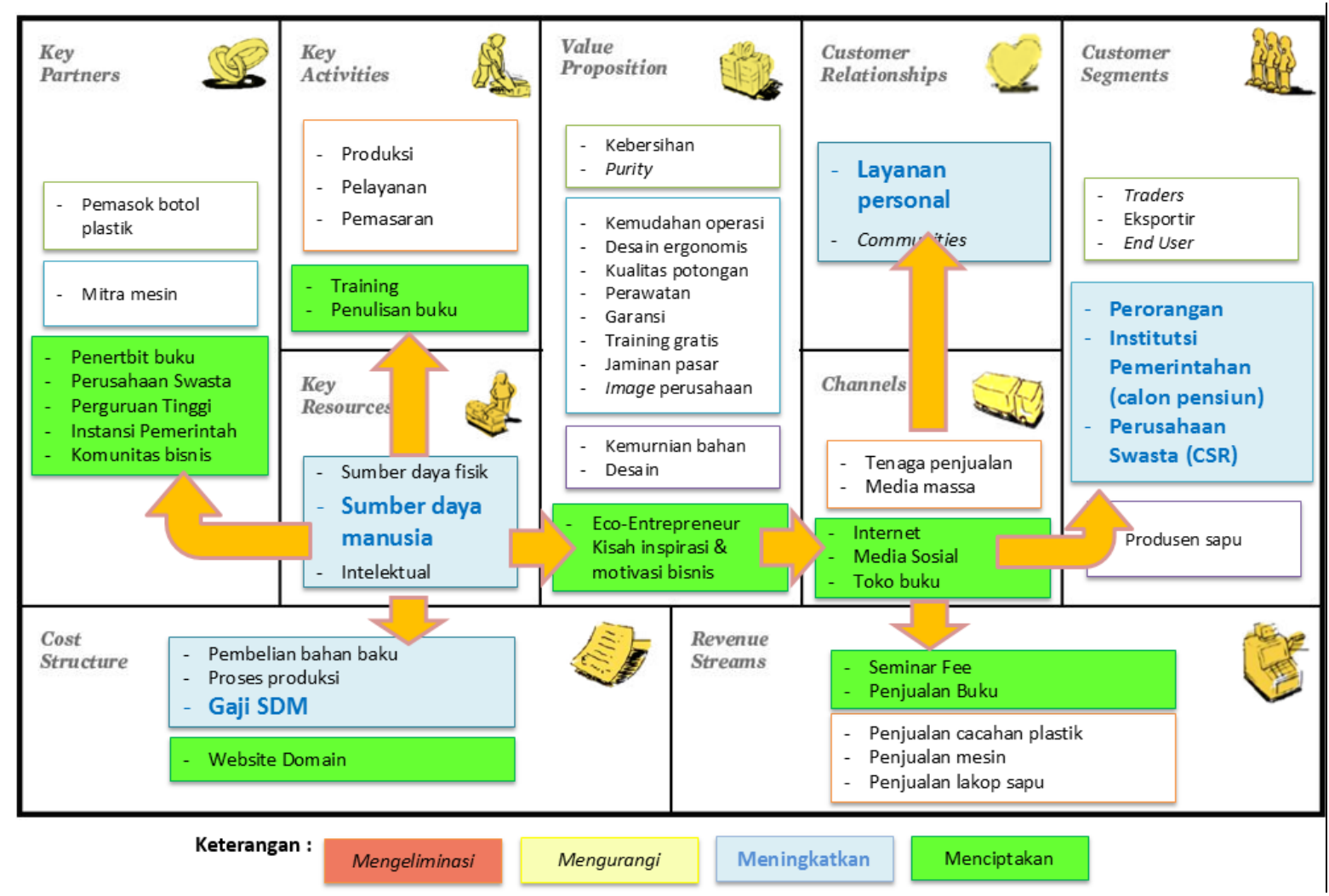

Gambar 3. Pengembangan model bisnis I CV Majestic Buana Group 


\section{b. Value Propositions}

Sejak menjadi topik pembahasan pada Konferensi PBB tahun 1972 di Swedia hingga saat ini isu lingkungan tidak pernah berhenti menjadi perhatian masyarakat. Isu lingkungan terus berkembang seiring dengan semakin tingginya jumlah populasi, tingkat pendidikan dan kesadaran masyarakat akan pentingnya lingkungan hidup. Dengan pertimbangan tersebut maka value yang dapat digunakan pada seminar/training bisnis adalah berbasis lingkungan atau Ecopreneurship. Hal ini diharapkan dapat meningkatkan minat pada bisnis daur ulang sampah plastik dan mitra bisnis MBG.

\section{c. Key Partners}

Partner utama yang perlu diciptakan untuk mendukung kesuksesan kegiatan penulisan buku adalah penerbit. Key partners yang dapat dirangkul MBG untuk kegiatan seminar/training bisnis meliputi perguruan tinggi, perusahaan swasta, instansi pemerintah dan komunitas bisnis. Hubungan yang dibentuk dengan key partners tersebut adalah hubungan kemitraan sebagai penyedia layanan jasa seminar/training. Perusahaan swasta yang berskala besar baik lokal maupun multi-nasional seringkali mengadakan program CSR (Corporate Social Resposibility) yang diimplementasikan dalam berbagai kegiatan, seperti pengadaan seminar/training bisnis untuk karyawan, masyarakat atau mahasiswa.

\section{d. Customer Segments}

Segmen pelanggan yang menjadi target penjualan buku adalah masyarakat usia remaja dan dewasa, sedangkan target pelanggan ecopreneurship terdiri dari mahasiswa/pelajar, calon pensiunan pegawai dan masyarakat peminat bisnis. Pembagian tersebut disesuaikan dengan kebutuhan dan permasalahan masing-masing segmen, sehingga diharapkan materi yang diberikan dapat lebih diterima.

\section{e. Channels}

Channels yang perlu dibangun untuk melakukan komunikasi dan pemasaran intensif adalah internet dan media sosial (medsos). Kedua channels tersebut perlu diciptakan untuk membangun kesadaran dan mengevaluasi proporsi nilai yang diberikan, serta memberi dukungan purna jual. Kesadaran yang perlu dibangun ditujukan pada pentingya pengelolaan sampah plastik yang baik, serta berbagai peranan yang telah dilakukan MBG, sehingga dapat memberikan contoh yang baik pada masyarakat.

\section{f. Customer Relationship}

Unsur customer relationship (hubungan pelanggan) perlu ditingkatkan melalui layanan personal dengan memanfaatkan channels social media (sosmed) yang dibangun perusahaan. Hal ini terutama dilakukan untuk mempertahankan dan meningkatkan intensitas komunikasi dengan pelanggan dan calon pelanggan. Layanan otomatis juga dapat dilakukan misal melalui profil online (website) yang memberikan kebebasan pelanggan (calon) untuk mengakses kebutuhan informasi yang diinginkan. Menurut Osterwalder dan Pigneur (2015), layanan otomatis dapat meniru hubungan personal, misal menawarkan dan merekomendasikan produk.

\section{g. Cost Structure}

Unsur cost structure yang perlu ditambahkan adalah gaji karyawan yang khusus bekerja untuk membuatan materi training. Selain itu, untuk mendukung pembuatan materi training yang interaktif, MBG perlu menggunakan sumber daya out sourcing yang memiliki keahlian dibidang media komunikasi untuk membantu membuat materi presentasi atau video-video penunjang presentasi yang menarik.

\section{h. Revenue Streams}

Memahami kesediaan membayar pelanggan terhadap proporsi nilai yang ditawarkan perusahaan merupakan faktor kunci pada unsur revenue streams. Untuk itu, perusahaan harus dapat terus mengevaluasi proporsi nilai yang diberikan sehingga transaksi dapat terjaga dan terus meningkat seiring dengan terciptanya pembelian berulang.

\section{Pengembangan Model Bisnis II}

Tingginya hasil penilaian kekuatan dipengaruhi oleh kemampuan MBG dalam menjaga mitra agar tidak mudah beralih menjual bahan baku (botol plastik) kepada pesaing melalui penawaran harga yang kompetitif. Pada sisi ancaman, hasil evaluasi memeroleh penilaian yang tinggi disebabkan sifat mitra (pemasok) sangat sensitif terhadap harga. Selain itu dari hasil analisis lingkungan terlihat bahwa ketersedian bahan baku merupakan faktor penting untuk menjaga kontinuitas produksi cacahan plastik. Untuk mendukung hal ini, pengembangan model bisnis ke II ditekankan pada menciptakan mitra baru yang nimim persaingan, yakni dengan berbagai sentra penghasil sampah plastik seperti 
instansi dan industri/pabrik yang menghasilkan sampah plastik dalam volume tinggi. Adanya penambahan mitra baru tersebut secara bertahap akan mengurangi ketergantungan dengan mitra pemasok sebelumnya (pemulung, pengepul dan lapak). Pengaruh perubahan unsur key partners terhadap unsur model bisnis lainnya pada Gambar 4.

\section{a. Key Activities}

Kementerian Lingkungan Hidup dan Kehutanan menghimbau, "Sesuai Amanat UndangUndang No. 18 tahun 2008 tentang Pengelolaan Sampah, menegaskan paradigma pengelolaan sampah saat ini harus diubah dari kumpulangkut-buang menjadi pengurangan dari sumber dan daur ulang sumber daya". Keputusan menciptakan partnership dengan sentra penghasil sampah plastik merupakan tindakan yang mendukung pengurangan sampah dari sumbernya sebagaimana arahan menteri tersebut. Bentuk aktivitas kunci yang dilakukan berupa perjanjian kerjasama atau kesepakatan kerja yang menguntungkan antara kedua belah pihak, yakni MBG pihak yang berperan mengolah sampah plastik dan sentra penghasil sampah berperan sebagai penyedia bahan baku berupa sampah plastik.

\section{b. Key Resources}

Key resources yang harus ditingkatkan untuk mendukung kerjasama kemitraan dengan sentra penghasil sampah plastik adalah peningkatan mutu SDM. Sentra-sentra penghasil sampah plastik umumnya telah memiliki kebijakan pengelolaan sampah yang dihasilkan. Adanya penawaran kerjasama dapat memengaruhi kebijakan tersebut. Untuk itu, diperlukan SDM dengan mutu yang mumpuni dari sisi pendidikan, pengetahuan, pengalaman dan manajemen yang dijalankan MBG untuk mendukung proses negosiasi dan pemutusan kerjasama dengan manajemen sentra-sentra panghasil sampah plastik tersebut.

\section{c. Cost Structure}

Penambahan key partners berupa kerjasama dengan sentra penghasil sampah plastik dapat mengurangi biaya pembelian bahan baku namun menambah pengeluaran untuk membuat kesepakatan kerjasama dengan mitra baru sentra penghasil sampah plastik. Keuntungan yang diharapkan dari kerjasama tersebut adalah menurunkan persaingan harga untuk memperebutkan sumber bahan baku (sampah botol plastik) yang selama ini diperoleh dari pemulung, lapak dan pengepul (pemasok).

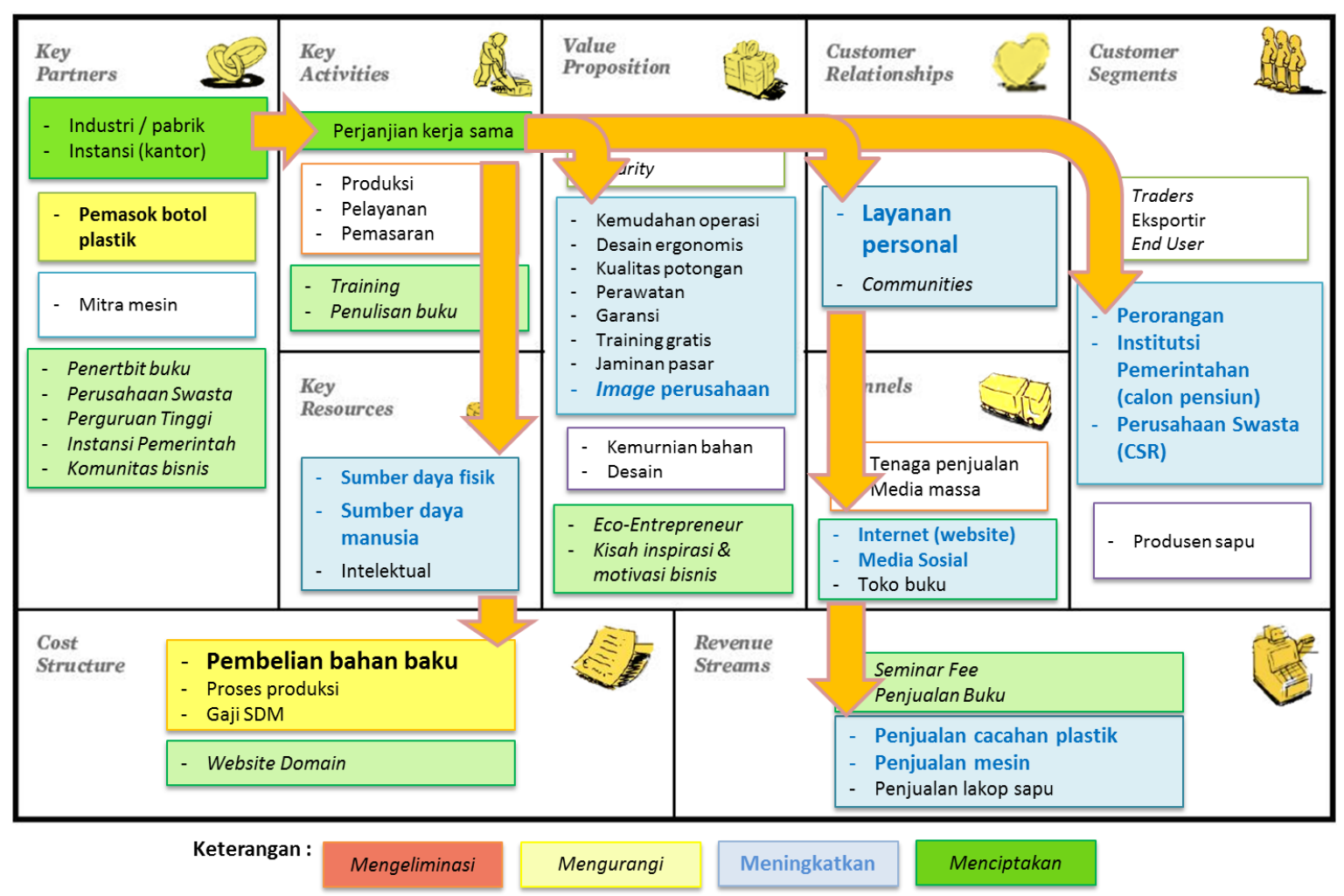

Gambar 4. Pengembangan model bisnis II CV Majestic Buana Group 


\section{d. Value Propositions}

Terkait dengan penciptaan kerjasama dengan sentra penghasil sampah plastik, maka perusahaan perlu meningkatkan value propositions yang telah dimiliki khususnya citra sebagai perusahaan daur ulang sampah yang berprestasi. Adanya citra yang baik akan meningkatkan kepercayaan (trust) calon mitra. Nilai lain yang perlu diciptakan adalah penyelesaian pekerjaan, pengurangan biaya dan kenyamanan. Kerjasama kemitraan yang ditawarkan MBG perlu ditekankan dalam bentuk bantuan menyelesaikan pekerjaan dengan cara mengelola sampah plastik yang dihasilkan oleh calon mitra (sentra penghasil sampah plastik), sehingga dapat mengurangi biaya pengelolaan sampah dan merasakan kenyamanan.

\section{e. Customer Segments}

Kerjasama dengan mitra sentra penghasil sampah plastik merupakan kerjasama yang harus dibangun dalam jangka panjang. Menurut Oktariana et al., (2012), kerjasama kemitraan jangka panjang memerlukan derajat komitmen lebih tinggi dan rasa saling percaya di mana kedua belah pihak bersedia menyediakan sumber daya secara adil dan dapat diandalkan untuk menjaga dan mencapai tujuan dari keduanya. Untuk mencapai hal tersebut diperlukan peningkatan bantuan personal kepada calon mitra baru perusahaan untuk memperoleh informasi yang jelas mengenai MBG dan kerjasama yang ditawarkan.

\section{f. Channels}

Channels dapat digunakan untuk menyalurkan proporsi nilai dan meningkatkan kesadaran calon mitra (sentra penghasil sampah plastik) tentang reputasi dan citra MBG. Untuk mendukung terciptanya hubungan jangka panjang, maka channels perlu memerhatikan informasi yang mengandung lima kriteria, yakni membangun awereness, evaluation, purchase, delivery dan after sales. Melalui kelima kriteria informasi channels tersebut diharapkan seorang calon mitra dapat terbentuknya kerjasama. MBG dapat melakukan hal tersebut dengan cara mamaksimalkan fungsi saluran tindak langsung, yakni internet (website) dan medsos.

\section{g. Revenue Streams}

Unsur ini mendeskripsikan pemasukan yang biasanya diukur dalam bentuk aliran uang yang memungkinkan perusahaan tetap hidup dan bukan representasi dari keuntungan yang didapat. Banyak perusahaan yang dapat membuka aliran masuk dari sumber pendapatan lain bukan dari pelanggan langsung. Penciptaan hubungan kerjasama dengan berbagai sentra penghasil sampah plastik secara tidak langsung dapat meningkatkan aliran pendapatan melalui pengurangan biaya pembelian bahan baku. Selain itu, penjualan mesin dapat meningkat seiring dengan besarnya kemungkinan karyawan sentra penghasil sampah plastik untuk menjalin kemitraan secara personal dengan MBG.

\section{Pengembangan Model Bisnis III}

Pengembangan model bisnis dengan BOS merupakan cara perusahaan melakukan diferensiasi mendasar bukan bersaing dengan industri yang sudah ada. Perusahaan dituntut meningkatkan nilai untuk pelanggan dengan menciptakan manfaat dan layanan baru yang memanfaatkan peluang dan mencari keuntungan dari modelmodel yang telah terbentuk. Hasil evaluasi unsur value propositions menunjukkan adanya kekuatan dan peluang yang tinggi. Menurut Allee (2000), kunci bisnis adalah bagaimana sebuah nilai yang diciptakan. Besarnya kekuatan dipengaruhi kemampuan melakukan inovasi mesin pencacah plastik, sebaiknya dimanfaatkan meraih besarnya peluang pasar dengan cara meningkatkan differensiasi produk yang memiliki biaya yang lebih murah. Hal ini dapat dilakukan dengan menawarkan desain mesin pencacahan plastik skala rumah tangga, sehingga dapat memperkuat value propositions dan menjangkau pasar yang lebih luas. Dampak tarik-menarik setiap unsur model bisnis MBG karena adanya penambahan value mesin (Gambar 5).

\section{a. Key Activities}

Penciptaan nilai baru dalam bentuk desain mesin pencacah plastik berskala rumah tangga merupakan terobosan yang sangat memengaruhi key activities. Pengaruh tersebut menyasar pada kegiatan produksi, pemasaran dan pelayanan. Pengaruh pada kegiatan produksi antara lain berupa perancangan desain mesin, prototyping dan QC. Pengaruh pada aktivitas pemasaran berupa peningkatan aktivitas pemasaran untuk memperkenalkan produk baru. Seiring dengan kegiatan penjualan maka kegiatan pelayanan juga akan meningkat terutama untuk pelanggan mesin baru berskala rumah tangga tersebut. 


\section{b. Key Resources}

SDM yang sangat berperan adalah owner MBG karena merupakan satu-satunya SDM perusahaan yang memiliki kapabilitas dibidang inovasi mesin. Kemampuan tersebut merupakan dasar menciptakan desain mesin yang memiliki mutu dan kinerja yang tinggi. Kemampuan owner dalam berinovasi tersebut sekaligus menjadi sumber daya intagible perusahaan yang termasuk pada kekayaan intelektual. Dari sisi sumber daya fisik, pembuatan mesin berskala rumah tangga akan memerlukan tambahan bahan baku seperti besi atau berbagai ondersil baru yang berbeda dengan mesin yang sudah ada sebelumnya.

\section{c. Cost Structure}

Unsur yang turut terpengaruh terhadap perubahan value propositions adalah biaya pembelian bahan baku, proses produksi dan gaji karyawan. Peningkatan biaya (cost) pada ketiga faktor tersebut akan sebanding dengan peningkatan aktivitas kunci yang dilakukan (key activities). Biaya pembelian bahan baku dapat meningkat menurut banyaknya kebutuhan bahan baku untuk pembuatan mesin baru. Hal ini juga terjadi pada biaya proses produksi dan gaji karyawan yang sebanding dengan biaya bertambahnya aktivitas produksi yang dilakukan untuk membuat mesin baru.

\section{d. Key Partners}

Pembuatan mesin berskala rumah tangga dapat menambah jumlah mitra mesin, sekaligus mitra penyedia bahan baku cacahan plastik. Jenis mesin ini memiliki segmen pelanggan berbeda dari pelanggan mesin sebelumnya. Keberadaanya dapat menambah jumlah pasokan bahan baku cacahan plastik dengan volume yang lebih kecil dibandingkan mitra industri. Untuk itu, perusahaan dapat menghubungkan mitra mesin berskala rumah tangga dengan mitra mesin berskala industri. Mitra mesin berskala industri dapat menjadi perpanjangan tangan MBG untuk memeroleh bahan baku yang lebih banyak dari para mitra mesin berskala rumah tangga.

\section{e. Customer Segments}

Nilai baru yang diciptakan berupa mesin berskala rumah tangga yang memiliki segmen berbeda dari segmen yang sudah ada. Sasaran segmen pelanggan mesin baru ini adalah bank sampah atau pengepul yang ingin meningkatkan nilai jual sampah botol plastik yang mereka kumpulkan dengan cara mengolahnya cacahan plastik sebelum dijual kepada pengepul yang lebih besar. Jenis hubungan yang harus dibangun untuk memerkuat key partners baru tersebut harus didorong oleh motivasi untuk meningkatkan penjualan (upselling) melalui penambahan proses added value.

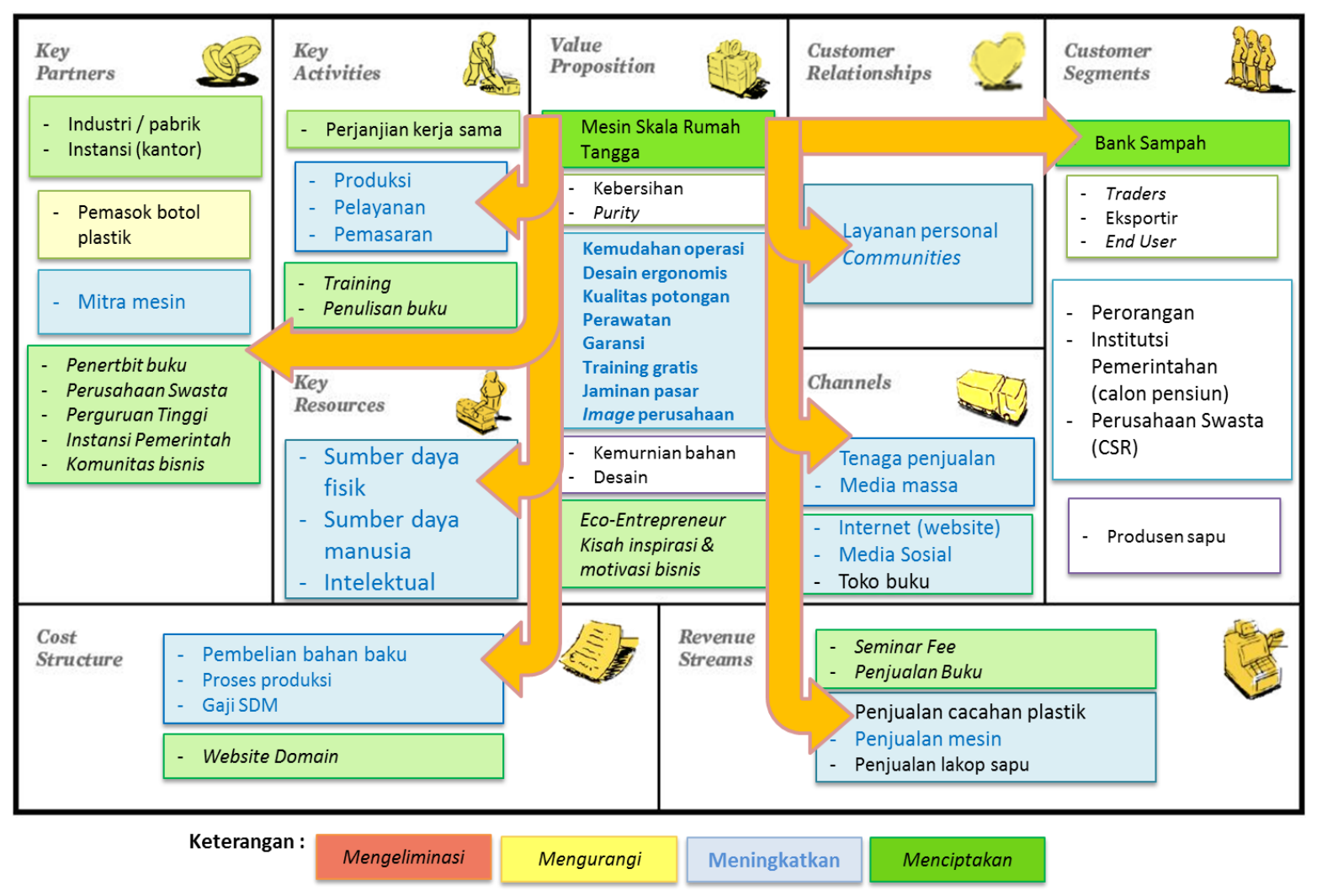

Gambar 5. Pengembangan model bisnis III CV Majestic Buaya Group 


\section{f. Customer Relationship}

Sebuah organisasi harus memperjelas tujuan customer relationships, apakah untuk mendapatkan pelanggan, memertahankan pelanggan atau untuk menghasilkan revenue dari pelanggan (Clark et al. 2012). Pada pengembangan model bisnis III ini tujuan customer relationships adalah mendapatkan dan memertahankan pelanggan. Penjualan mesin baru berskala rumah tangga memiliki segmen pelanggan yang berbeda dari segmen pelanggan mesin yang ada sebelumnya. Tujuan customer relationship untuk segmen pelanggan baru adalah mendapatkan dan meningkatkan jumlahnya. Sementara itu, customer relationships harus meningkatkan perannya dalam mempertahankan pelanggan lama dengan cara menjadikannya sebagai perpanjangan tangan MBG untuk mendapatkan supply cacahan plastik dari para mitra baru.

\section{g. Channels}

Kebijakan untuk membuat mesin berskala rumah tangga merupakan terobosan baru yang belum dikenal masyarakat secara umum. Channels harus bisa menciptakan awareness, menyampaikan nilai yang terkandung dan membuat calon pelanggan untuk melihat informasi produk secara lengkap, sehingga bisa mengevaluasi produk baru perusahaan. Keberadaan channels seperti ini diharapkan dapat memperkuat brand image MBG. Cara yang bisa dilakukan adalah dengan meningkatkan performa channels yang sudah ada yakni melalui media tradisional seperti media masa/koran, internet seperti sosial media dan website serta tenaga penjual langsung.

\section{h. Revenue Streams}

Saran yang diberikan adalah meningkat pendapatan dan margin. Revenue streams perusahaan meningkat seiring dengan peningkatan penjualan mesin baru perusahaan dan loyalitas yang terbentuk.

\section{KESIMPULAN}

Berdasarkan hasil analisis yang telah dilakukan, maka pengembangan model bisnis $\mathrm{CV}$ MBC dapat dilakukan melalui:

1. Unsur key resources yang didasarkan pada arah pengembangan perusahaan untuk melakukan transfer knowledge, sehingga semakin banyak pelaku bisnis daur ulang sampah plastik. Hal ini dilakukan dengan meningkatkan kapasitas owner MBG melalui pembuatan buku dan penulisan seminar.

2. Unsur key partners dari hasil evaluasi SWOT menunjukkan adanya kelemahan dan ancaman tinggi, sehingga perlu diantisipasi melalui kemitraan/kerjasama dengan sentra-sentra penghasil plastik seperti sekolah atau gedung perkantoran.

3. Unsur value propositions dari hasil evaluasi menunjukkan adanya ancaman tinggi, sehingga perlu diantisipasi melalui pemanfaatan kekuatan perusahaan dengan melakukan ivonasi mesin dalam bentuk skala rumah tangga, sehingga kegiatan daur ulang sampah plastik dapat dilakukan dalam skala bisnis yang lebih kecil.

\section{ACKNOWLEDGMENTS}

Ucapan terima kasih disampaikan kepada Lembaga Pengelola Dana Pendidikan Kementerian Keuangan (LPDP Kemenkeu) yang telah memberikan bantuan dana penelitian (Beasiswa Tesis) dan Bapak Mohammad Baedowy, SE yang telah memfasilitasi jalannya penelitian di $\mathrm{CV}$ MBG.

\section{DAFTAR PUSTAKA}

Allee, V. 2008. Value network analysis and value conversion of tangible and intangible assets. Journal of Intellectual Capital, Vol. 9 No. 1, pp. 5-24

Amanullah, ANAA., NFA. Aziz, FNHAH. Hadi, J. Ibrahim. 2015. Comparison of Business Model Canvas (BMC) Among the Three Consulting Companies. International Journal of Computer Sciences and Information Technology Research Vol.3 Issue 2, pp: (462471)

[Antara]. 2015. Indonesia perlu kerja keras tangani sampah. www.antara.net.id (7 Desember 2015)

Chaerul, M., AR. Fahruroji, T. Fujiwara. 2014. Recycling of Plastic Waste in Bnadung City, Indonesia. Journal Mater Cycles Waste Manag 16:509-518. DOI 10.1007/s10163-013-0201-2

Clark, OA., Y. Pigneur. 2012. Business Model You. Hoboken (LN): New Jersey.

Fielt, E. 2011. Understanding Business Models. Journal Business Service Management Whitepaper. 3. 
Jambeck, JR, R. Geyer, C. Wilcox, TR. Siegler, M. Perryman, A. Andrady, R. Narayan. 2015. Plastic waste inputs from land into the ocean. Journal of Science. 347: 768-771.

[KLH] Kementerian Lingkungan Hidup dan Kehutanan. 2015. Rangkaian HLH 2015dialog penanganan sampah plastik. www.menlh.go.id (7 Desember 2015)

Kim, WC., R. Mauborgne. 2005. Blue Ocean Strategy: How to Create Uncontested Market Space Competiton Irrelevant. Boston (LN): Harvard Business School Press.

Meidiana, C., T. Gamse. 2010. Development of Waste Management Practices in Indonesia. European Journal of Scientific Research. ISSN 1450-216X Vol.40 No.2 (2010), pp.199-210

Nelms, SE., EM. Duncan, AC. Broderick, TS. Galloway, MH. Godfrey, M. Hamann, PK. Lindeque, BJ. Godley. 2015. Plastic and marine turtles: a review and call for research. ICES Journal of Marine Science. doi:10.1093/icesjms/ fsv165

[Harian Ekonomi Neraca]. 2013. Omzet industri kemasan diperkirakan 50 T. www.neraca. co.id (7 Desember 2015).
Oktariana, Y., A. Fauzi, S. Kumadji. 2012. FaktorFaktor Customer Relationship Management (Manajemen Hubungan Pelanggan) dalam Mewujudkan Kepuasan Anggota dan Dampaknya terhadap Loyalitas Anggota (Survey Pada Anggota Koperasi Nusantara Cabang Malang Di Kantor Pos Besar Malang). Jurnal Profit Vol.3 No.2 (2012), pp: 149-162.

Osterwalder, A., Y. Pigneur. 2015. Business Model Generation (terjemahan). Jakarta (ID): PT Alex Media Komputindo.

Rangkuti, F. 2004. Analisis SWOT Teknis Membedah Kasus Bisnis. Jakarta (ID): Gramedia Pustaka Utama.

Sahwan, FL. 2005. Sistem Pengolahan Limbah Plastik di Indonesia. Jurnal Teknik Lingkungan P3TL-BPPT. 6.(1): 311-318

Suhartiningsih, W. 2000. Sistem Penunjang Keputusan Investasi Usaha Daur Ulang Sampah Kota untuk Produksi Kompos. Tugas Akhir [Tesis] Magister Manajemen dan Bisnis, IPB. 